\title{
SANATTA BİR ANLATIM NESNESİ OLARAK KUMAŞ
}

\author{
Gülşen Şefika BERBER* \\ Azize Reva BOYNUKALIN**
}

\begin{abstract}
Özet
Tarihi insanlığın başlangıcına dayanan; korunma, örtünme gibi içgüdüsel duygu durumlarını karşılayan kumaş, zamanla bedeni ve yaşamsal alanları doldurarak varlığını sürdürmüştür. Kumaş bu fiziksel misyonunun yanı sıra antik çağlardan günümüz sanatına kadar da bir ifade aracı olarak kullanılmıştır. $\mathrm{Bu}$ çalışmada kumaşın sanat tarihsel süreçte geçirdiği anlamsal dönüşümler incelenmiştir. Kumaşın sanat eserlerindeki üslup farklılıkları üzerinde durulmuş, sanat eserlerindeki anlambilimsel ve düşünsel katkıları incelenmiştir. Araştırmada nitel araştırma yöntemi kullanılarak literatür taraması yapılmış, veri toplamanın akabinde kumaşın antik çağlardan bugüne kadarki görüntüsel ve imgesel temsilleri açıklanmaya çalışılmıştır. Kumaşı bir temsil nesnesi olarak ele alan örnek eserler üzerinden kumaşın ilettiği metafor ve çözümlemeler ortaya koyulmuştur. Araştırmada özellikle kumaşın, Erken Rönesans döneminde natüralizm, kutsallık, saflık ve yücelik kavramlarıyla ilişkisine değinilmiştir. Modern sanatta ifade olanaklarının genişlemesi ile kumaşın duyulara hitap eden bir anlatım nesnesine dönüşmesi ve günümüze kadarki süreçte, değişen yeni anlatım olanakları ve temsilleri araştırılmıştır.
\end{abstract}

$\mathrm{Bu}$ çalışma, sanat tarihsel süreçte yer alan kumaş imgelerine farklı bir bakış açısı sunmayı amaçlamaktadır.

Anahtar Kelimeler: Kumaş, Temsil, Rönesans, Modernizm, Postmodernizm

\section{FABRIC AS AN OBJECT OF EXPRESSION IN ART}

\begin{abstract}
Its history dates back to the beginning of humanity; fabric that meets instinctive emotional states such as protection, covering continued its existence by filling the body and vital areas over time. In addition to this physical mission, fabric has also been used as a means of expression from ancient times to today's art. In this study, the semantic transformations of the fabric in the art historical process were examined. The stylistic differences of the fabric in the works of art were emphasized, and the semantic and intellectual contributions of the fabric in the works of art were examined. In the research, a literature review was made using the qualitative research method, and in the first stage of data collection, the visual and imaginary representations of the fabric from ancient times to the present were tried to be explained. The metaphors and analyzes conveyed by the fabric are explained through the sample works that deal with the fabric as an object of representation. In the research, especially the relationship of fabric with the concepts of naturalism, sanctity, purity and sublimity in the Early Renaissance period was mentioned. With the expansion of the possibilities of expression in modern art, the transformation of the fabric into an object of expression that appeals
\end{abstract}

\footnotetext{
* Öğr. Gör. Dr., Manisa CBÜ, Sa lihli Meslek Yüksek Okulu, Tekstil Giyim, Ayakkabı ve Deri Programı, gulsennberber@hotmail.com

Dr. Öğr. Üyesi., Sinop Üniversitesi, Güzel Sanatlar ve Tasarım Fakültesi, Resim Bölümü, azizereva@gmail.com
} 
to the senses and in the process, changing new expression possibilities and representations of the fabric have been researched until today.

This study aims to present a different perspective to fabric images in the art historical process.

Keywords: Fabric, Representational, Renaissance, Modernism, Postmodernism

\section{Giriş}

Antik çağlardan beri kendine özgü yapısı ve dokusu ile insanlığa örtünme ve barınma işlevi sağlayan kumaş, bedenin koruyucusu olma özelliği taşır. Doğumdan ölüme dek insanlığa farklı kullanım alanlarında eşlik eden kumaş, tarihsel süreç içerisinde sembolik anlamlar kazanarak kültürel bir değere dönüşmüştür. Kumaş, tene temas eden bir nesne olarak insanla psikolojik bir bağlantıya sahiptir ve bu yönüyle diğer nesnelerden ayrılır. Bunun yanında estetik, felsefi ve sosyolojik açıdan da kültürlere ve toplumlara göre çeşitli metaforik anlamlar içeren çok yönlü bir değerdir. Kumaş da insanlık gibi, yaşam sürecinin her aşamasında değişip gelişmiş, yeni kullanım biçimleri ve anlamlar kazanmıştır. Örneğin doğumda bebeğin sarınması için kullanılan kundak, kumaştandır. Ölmüş bedenin sarındığ 1 kefen de kumaştır. Ayrıcalıklı bir nesne olarak kumaş zamana, mekâna, olay ve durumlara bağlı olarak isim ve anlam değișikliğine uğrar. Ernesto Francalanci Nesnelerin Estetiği kitabında "eğer varoluşun her alanına yayılmış görüngü olarak postmodern durumun ve onun estetiğinin yayılmacı ve düzenleyici özelliğinin, simgesel bir nesnesini seçmek zorunda kalsaydık kumaşı gösterebilirdik” der (Francalanci, 2012, s. 199). Ayrıca kumaş, formdan forma girebilme özelliği ile yaşamın her alanında sosyo-kültürel bir değer taşımış ve kültür nesnesine dönüşmüştür. Kumaşlar etnik kökenler, toplumsal hiyerarşi, kimlik, kişilik, psikolojik etkenler gibi birçok durumu sembolik olarak ifade edebilme gücüne sahiptir. Özellikle kumaşın örtme kapatma özelliği onun felsefi açıdan farklılıkları zıtlıkları gizleyen bir metafora dönüştürür. Francalanci kumaşın dönemlere göre değişen anlamsal farklılıklarını şu şekilde ifade eder:
“Modern” kumaşın her zaman olumlu kavramsal bir anlamı vardır (örtme ve örtüsünü kaldırma aynı çözzümleyici hareketin iki kutbunu oluşturur: her şey gizlidir ama her şey araştırllabilir, kuşkulu biçimde olsa bile). 'Postmodern' kumaşın ise her zaman olumsuz bir işlevi vardır, ister farkları karıştırmak için kullanıldı̆̆ zaman olsun ister tersine kuşku ve belirsizlik yerlerinden uzaklaşarak köklü ve zoraki seçimleri dayattı̆̆l zaman olsun" (2012, s. 199).

Tüm sanat tarihi sürecine bakıldığında kumaşın farklı sembolik anlamlarının öne çıkması, onun ifadeci bir unsur olduğunun göstergesidir. Resim ve heykellerdeki şiirsel kullanımı tarih boyunca izlenebilen vizyoner bir geçmiş yaratmaktadır. Özellikle klasik sanat eserlerinde kumaşın farklı koşullar altında form değiştirebilme özelliğini gözlemlemek mümkündür. Farklı biçim ve dokulara bürünebilme özelliği, kumaşı sanat yapıtlarında kompozisyona katkı sağlayan yardımcı bir unsur haline getirmiştir.

Kumaşın örtücü özelliği ise başka metaforları devreye sokar. Örtü öyle mükemmel bir oksimorondur ki, gizlerken bakma ve dokunma istenci arasında bir tür mekanizma görevi görür. Kumaşın örtme özelliği, yücelterek saklamayı ortaya koyar. Ama aynı zamanda koruyarak yüceltmeyi de ifade eder. Örtme, kendi içerisinde koruma ve aynı zamanda sınırlandırma barındırır. Vücuda, nesneye, yapıya veya mecazi anlamda gerçeğin üstüne örtülen örtü her durum ve konuya uygulanabilir. Nesne ile bakış arasına mat bir şeffaflık, estetik bir maske ve mesafe koyar. Sanat 
tarihsel süreçte farklı ifade biçimlerini aktarmak için kullanılan kumaş, örtme özelliği ile oyunları, aldatmaları, gerçekleri ve yanılsamaları gizleyebilir.

"Batı sanatı tarihinde örtünün gösterilmesi zengin bir örnek ikonografisine sahiptir. Roma dininin Kutsal Ateş Rahibelerinden Hıristiyan katakomblarına kadar örtü farklı anlamlar içerir. Vestale inancında örtü, tanrının koruması altında hareket etme anlamına gelir.

Orante inanışında ise tam tersi insanın tanrlya boyun ĕgdiğini gösterir. Batı din ve sanat tarihinde 5. yüzyıldan 18. yüzyıla yani San Marco bazilikasından Raffaello'nun Velata eserine kadar örtü, basitten süslü ve karmaşı̆̆a, çizgiselden saçaklı ve işlemeliye kadar sonsuz sayıda değişkene uyum sağlar. Kutsal bir simge, bir tür dinsel üniforma olan örtü Rönesans modernitesinin ve sonra 16. yüzyıl maniyerist baskısının karşısında çöküntüye uğramıştır" (Francalanci, 2012, s.200).

Sanat tarihsel süreçte, kumaşın kullanımına dair üslup ve temsil biçimleri zaman içerisinde farkl11ık göstermektedir. Sanatta kumaşın dönem ve üsluplara göre farklı amaçlarda kullanılması veya yer alması değişen anlamsal çağrışımların ve metaforların gelişmesine yol açmıştır. Örneğin;

"Ortaçağ sanatı, zenginliği temsil eden zümrüt renklerinde kumaşı yatay eğimli biçimlerde kullanmıştır. Erken Rönesans'da kumaşlı heykeller biçim arayışını da beraberinde getirmiştir. Kumaşın şekillendirilmesi ve derinlik arayışı daha önemli hale gelirken, renkler biraz daha yumuşatılmış ve çeşitlenmiştir. Flaman sanatında ise kumaş çok ağır ve hacimli bir nesneye dönüşmüştür" (Hollender, 1975, s.416).

Heykelin yeniden "görünür" olmaya başladığı Romanesk ve Gotik dönem heykel sanat anlayışında, çoğunlukla kumaş katları daha kütlesel ve katı bir biçimde betimlenmiştir. Ancak Rönesans sanatı daha doğal ve akıcı bir kumaş stili görülür çünkü kumaşa ivme ve hareket kazandıranın bu akıcılık olduğu keşfedilmiştir. Sanat yapıtlarında daha abartılı duygu ve heyecanlar yakalamak için kumaş katlarının arttırılması bu dönemde uygulanan bir ifade yöntemidir. Gaiger, düşünce yapılarının biçimlendirmeye olan etkisini, Gilles Deleuze'ün, kumaşın katlanabilirliğiyle fikirlerin çok katmanlılığını özdeşleştirmesi üzerinden ifade eder (2003, s.279). Bu açıdan bakıldığında Rönesans'ın bir aydınlanma çağı olmasının resimlerde kullanılan yoğun kumaş katlarının yeni fikir ve düşüncelerin metaforik ifadesi olarak temsil edildiği söylenebilir. Sanatta dönemlere ve coğrafi konumlara göre değişen kumaşın temsilleri günümüze kadar farklı ifadesel açılımlarını sürdürmeyi başarmıştır.

\section{Sanatta Kumaş ve Değişen Temsilleri}

Sanat tarihi sürecinde, sanatın temsil kurulumu pek çok değişkene bağlı olarak farklılaşarak her dönemin ve toplumun kendi estetiğini bu temsil anlayışına göre biçimlendirmiştir. "Temsil bir olgunun, bir şeyin ya da nesnenin dışsal bir gerçekliğin, bir düzlemde, dil ya da düşüncede, ayn en, hiçbir anlam ve içerik kaybı olmadan yansıtılması, betimlenmesidir" (Cevizci, 1999, s.839). Temsil, bir nesnenin varlığına büründürmek anlamına gelmekle beraber soyut bir kavramın bir nesne veya imge aracılığ çağlarda Platon'un öne sürdüğü mimesis (taklit) kavramıyla başlamıştır. Dolayısıyla sanatta tem sil kavramı felsefe ile ilişkili olarak ortaya çıkar. Platon sanat ve sanat yapıtının ne olduğunu temsil kavramı üzerinden açılar. Platon'a göre sanat ideanın bir görüngüsü, taklididir (Platon, 2014, s.336-340). Platon'un bu öğretisi aynı zamanda Batı sanatının kuramsal alt yapısını da oluşturur. Nelson Goodman görsel sembol sistemlerinin kodlarını açıklarken, bir nesnenin kendisine en yüksek derecede benzediğini fakat nadiren kendi kendisini temsil ettiğini; benzemenin, temsilden 
farklı olarak, yansıtıcı (reflektif) ve simetrik olduğunu açıklamıştır (Goodman,1976, s.4). Bu bilgiler doğrultusunda sanatta kumaş nesnesine bakıldığında yalnızca bir nesne ya da malzeme olmanın dışında çoğunlukla soyut kavram ya da konuları temsil eden bir metaforla karşılaşılır.

Gotik dönem heykel sanatından on dokuzuncu yüzyılın sonlarına kadar uzanan süreçte, sanatçılar kumaşın etkileyici görsel gücünü sıklıkla kullanmışlardır. Resimde ise ifadeyi güçlendirmek için kompozisyonun büyük bir kısmını özellikle kumaşlara ayırmışlardır. Yirminci yüzyılda, sanatta kumaşın kullanımı yeni bir sanat anlayışı ile dönüşmüş ve geleneksel üsluptan kopmaya başlamıştır. Modern sanattan yüzyıllar önce eserlerde işlenen: kumaşın akışı ve ritmi, biçim bükülmeleri ve ani renk patlamaları gibi plastik unsurlar sonraki figüratif ressamlara ilham kaynağı olmuştur. Ancak kumaş imgesi, klasik resim sanatında sanatçının figürü büyütmesi için değerli bir araç haline gelirken, modern sanatta baskın bir özne olarak biçimsel nitelikleriyle ortaya çıkmaktadır.

Kumaşın estetik bir unsur olarak sanatta kullanımı sanat eleştirmenlerinin dikkatini çekmiş ve bu konuda farklı görüşler sunmuşlardır. Kumaşın hem temsil edilebilme hem de soyutlanmış bir form gibi görünebilme özelliği, onun sanatta özne olarak var olabildiğinin kanıtıdır. "Kumaşın kırışıklıkları, kıvrımları, şekilleri ve genel formunun esnekliği, belli belirsiz soyut hale gelebilme özelliği, geleneksel sanat ile modern sanat arasında ilginç kavramsal bir geçiş yaratmaktadır" (Brady ve Barton, 2013). Anne Hollender Kumaş İmgesi: Örtünün Sanattaki Rolü isimli kitabında, farklı sanat eleştirmenlerinin estetik bir unsur olarak kumaşa dair görüşlerini derlemiştir. Hollender derlemesinde, Georges Woolishcroft Rhead Klasik dönem sanatçılarının kumaşın renk ve dokusunu ifade etmedeki başarılarının çağdaş sanatçılarda görülemediğini belirtmiştir. Çağdaş sanatçıların kumaşı ayrıntılı betimleme konusunda yeterli bilgiye sahip olmadıkları halde onu vazgeçilemez bir imge olarak kullanmaya devam ettiklerine dikkat çekmiştir. Lord Leighton ve Alma Tadema gibi ressamların eserlerindeki abartılı kumaş kullanımının teknik ustalık ve üslup kontrolü ile çağdaşlarına nazaran çok daha ikna edici olduğunu vurgulamıştır. Charles Baudelaire ve Oscar Wilde ise sanat eleştirmenleri olarak hem modern hem de geleneksel kumaşı içerecek birleşik bir güzellik kavramı yaratma sorununa dikkat çekmişlerdir. Baudelaire, Rönesans kumaş kullanımından ziyade daha modern bir anlayışı önerirken Oscar Wilde modern sanattaki kıvrımlı kumaş kullanımını reddetmektedir (1975, s.413-416).

On yedinci yüzyıl Batı resimlerindeki kumaşın çekici güzelliği, muazzam ifade gücü birçok yazarının dikkatini çekmiştir. Jhon Ruskin, Venedik'in Taşları isimli kitabında klasik portre resimlerindeki kumaşların görkemine ve temsil ettikleri asillik kavramına dikkati çekmektedir. "Uzun elbiselerdeki kumaşların etrafa yayılan hayali kıvrımlarının güzelliği nedir ki? Burada güzellikten daha fazlası vardır” (Hollender,1975, s.416) sözüyle Ruskin, görkemli uzun kumaşları; karakterin, saygınlığın ve nezaketin temsili olarak tanımlamaktadır. On sekizinci yüzyılın ortalarında William Hogarth da "uzun kıvrımlı" kumaşın asaletle olan ilişkisini vurgulamıştır. Kumaş kıvrımlarının asaleti ve yüceliği temsil etmesinin en doğal ve belirgin örneğini Eski Yunan'da görmek mümkündür. Eski Yunanlılar, yünlü kumaşlarını evde yapmış ve bu geleneği y1llar boyu sürdürmüşlerdir. Doğadan elde edilen kumaş, onlar için, yağ veya süt gibi organik bir malzemedir. Orta çağ Avrupalıları ise kumaşla çok haşır neşir olmadıklarından onu doğal bir malzeme olarak benimsememişlerdir. Aksine kumaşı ekonomik gelir kaynağı olarak görmüşlerdir. Bu dönemde kumaş, maddi bir töz olarak, altın ya da cam statüsünde bir değere sahiptir. Dolayıs1 ile bu dönemde insanın maddiyata yönelik dürtüsünü temsil etmektedir. Bu nedenle, tıpkı değerli metallerde olduğu gibi, kumaşın dokusunun, renginin, ağırlı̆̆ının ve kendine has özellikleri onun değerini etkilemektedir (Hollender,1975, s.421). Kumaş sanatta hayal gücünü besleyen bir unsur olarak öne çıkmıştır. Batı sanatında kumaş daha çok ruhla bütünleştirilmiş ancak bedenden ayrı tutulmuştur. Ayrıca "örtme" ve "örtünme" kavramları da kumaşa bağlı olarak ortaya çıkmış, bedeni güzelleştiren bir unsura dönüşmüştür. Örneğin Rönesans resimlerinde yer alan melekler, kanatlar 
yerine uzun görkemli kumaşlarla betimlenmiştir. Kumaş Rönesans’ta bedenden daha saf bir imgedir ve güzelliği temsil eder. Dolayısıyla kumaşın resimlerdeki yoğun kullanımı cennetin güzelliğini vurgulamayı amaçlamaktadır.

Erken Rönesans dönemi resim sanatında kumaş imgeleri kompozisyonun ayrılmaz bir parçasıdır. Ancak bazı eserlerde renk ve biçim özellikleriyle resmin gizli tarihi olarak adlandırılabilecek kadar hayati önem taşımaktadır. Erken İtalyan resminin iki önemli ressamı Duccio ve Giotto, (Görsel 1 2) kumaşı farklı şekillerde kullanabilen iki sanatçıdır (Dixon, 2016).

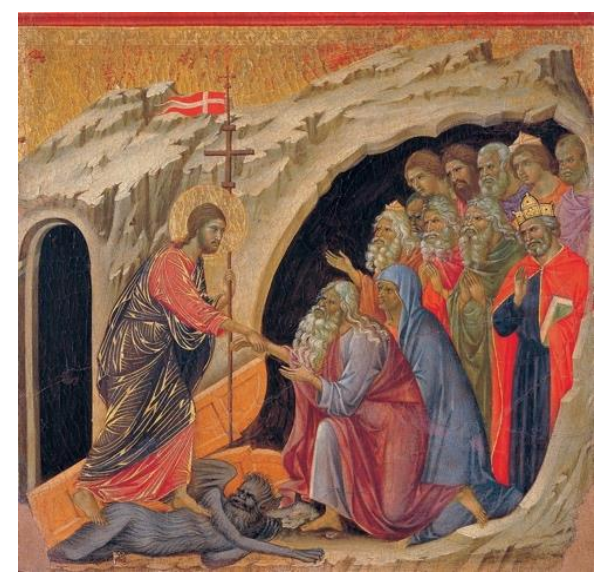

Görsel 1: Duccio diBuoninsegna, Maestà Cephesi, PanelüzerineFresk, 214x21 7cm 1308-1311

Duccio "Maesta Cephesi” resminde hikâyenin derinliğini, İsa'nın tutkusunu vurgulayabilmek için ince ipek kumaşları özenle ve ustalıkla boyamıştır. Birkaç panelden oluşan bu duvar resminde İsa, diğer figürler arasında kıvrımlı altın ipliklerle örülmüş elbise giyen tek kişidir. Dolayısıyla "Maesta Cephesi” resmindeki her panelde İsa figürünü ayırt etmek oldukça kolaylaşmıştır. Bu altın 1şı1tılar saçan kumaş, ölüme ve ötesine doğru hareketi yani dirilmeyi ve kaderin sürüklediği her türlü sikıntıda kusursuz kalabilmeyi temsil etmektedir.

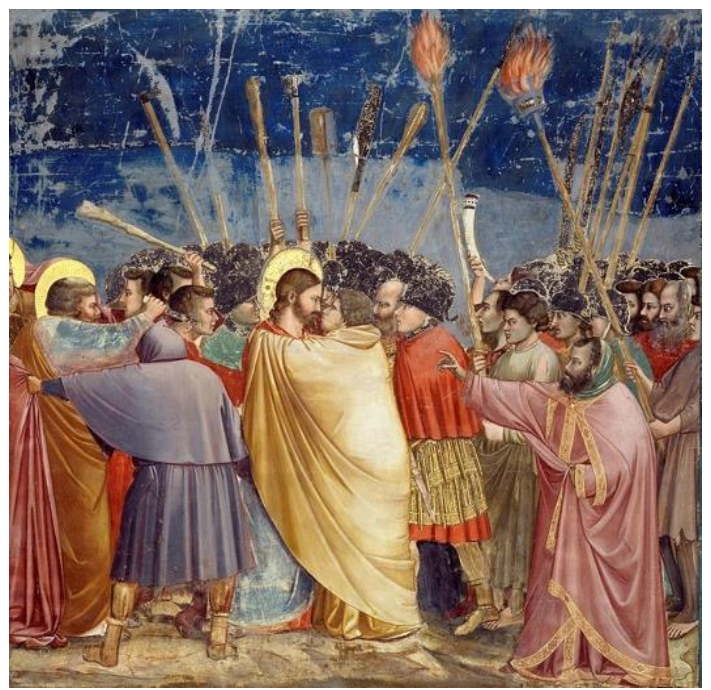

Görsel 2: Giotto, Yahuda’nın Öpücüğ̈̈, Fresk Tekniği, 215x230cm, 1303-05

Giotto, Duccio'nun aksine resimde kumaşı çok daha anıtsal bir biçimle kullanmıştır. Arena Şapeli fresklerindeki tüm figürler, mermerden oyulmuş gibi görünen devasa kumaş kıvrımlarıyla 
örtülmüştür. Sanatçı, kumaşın saf ağırlığını bir ifade aracı olarak kullanır. Resimde görülen ihanet sahnesinde, Yahuda İsa'yı öperken, İsa'nın bedenini de pelerininin içine sokar. "Sanki giydiği giysilerle İsa’ya hazırladığı ihanet dünyasının duvarlarını örmektedir” (Dixon, 2016).

Avrupa' da Rönesans döneminde hem Fransa hem de İtalya'da on üçüncü yüzyıl heykeltıraşlığında görülen natüralizmin yeniden ortaya çıkışı, Avrupa sanatında kumaşın üslup dönüşümünde keskin ayrımlara yol açtırmıştır. Ancak daha da önemlisi, bu dönemde beden ve kumaş arasındaki bağlantıya yönelik tutum değişikliğinin ortaya çıkmasıdır. Hem İtalya' da hem de Kuzey'de Erken Rönesans'ın yeni gelişen natüralist anlayışında resimlerdeki kumaş betimlemeleri, Hıristiyan inancındaki bedeni gizleme fikriyle örtüşmektedir. Kumaşın, hikâyeyi canlandıran figürler kadar başrolde olduğu bir başka resim, Sandro Botticelli'nin ünlü resmi, Venüs'ün Doğuşu' dur (Görsel 3). Eserde Tanrıça çıplaktır ve kendisini denizden karaya taşıyan kabuktan çıkarken vücudu yalnızca sarı saçlarının kıvrımları ile örtülüdür. Dünyaya gelişi, bekâretinden vazgeçmesinin simgesidir. Ancak resmin anlamı kumaş imgesiyle okunduğunda tam olarak ortaya çıkar. Sahnede Tanrıça yeryüzüne gelirken, hizmetçisi onu çiçeklerle işlenmiş ten rengi bir örtüyle sarmak için ilerler.

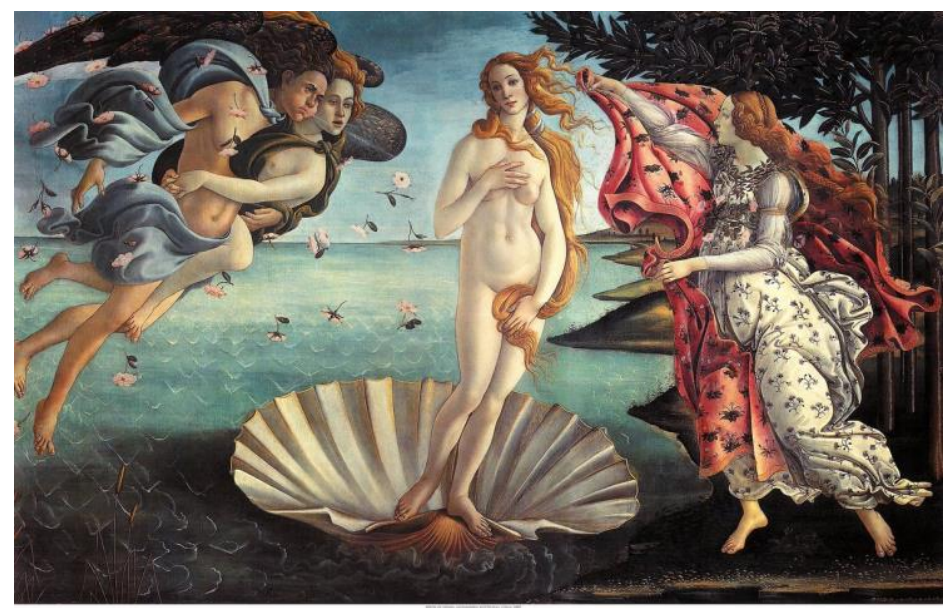

Görsel 3: Sa ndro Botticelli, “Venüs’ün Doğuşu” Tuvalüzerine Tempera, 172 cm x 278 cm, 1482-1486

Resimde bu örtü, kaderi, dünyevi yaşama bürünmeyi ve rahminin meyve vermesinin sembolüdür. "Resmin tepesinde, Venüs'ün hüzünlü güzel yüzünün yanında kumaşın bir tutamı hizmetçinin dikkatli parmaklarıyla vajina biçiminde şekillendirilmiştir. Sanatçı özenle hazırlanmış bu vulva görüntüsünün içine tek bir yeşil yaprak yerleştirmiştir” (Dixon, 2016). Botticelli'nin kumaşı o kadar özenle boyanmıştır ki cinselliği törensel bir ciddiyetle ifade eder. Bundan sonraki dönemde de mitolojik konuları işleyen ressamlar, kumaş imgelerini daha görkemli ve hacimli resmetmişlerdir.

On yedinci yüzyılda, Nicholas Poussin'in büyük ölçüde kumaş kullanım geleneği dikkat çeker. Poussin'in resminde kumaşlar uhrevi dansçılar gibi özgürce yayılır. Dikkat çeken renk ritimleriyle hareket ve enerjiyi arttırır. Asit sarısı, açık turuncu, buz mavisi gibi rüzgârda dalgalanan kumaşlar, Mondrian'ın bölünmüş karelerden oluşan soyut ve ideal resim anlayışını öncülleri olarak yorumlanabilir.

Kumaş genellikle ressamlar için bir kaçış yolu olmuştur ve gerçeklikten uzaklaşarak somut dünyayı temsil etme zorunluluğundan kurtulmuşlardır. Özellikle Rubens'in resimlerinde kumaşlar duyguların ifadesidir. "Rubens resimlerinde kumaşların renk zenginliği arzu ve büyülenme duygusunu harekete geçirir. Renkli kumaşlar onun eserlerinde, güç ve lüksün görsel dilinin bir parçası haline gelmiştir" (Dixon, 2016). Gösterişli Rubens stili dökümlü kumaş algısı, Fransız devriminden önce portre resimlerinde de kendini göstermiştir. Rigaud ve Largillière'in portrelerini 
baktığımızda kralların ve soyluların resimlerinde, kompozisyon boyunca akan ipeksi kumaşlar zenginliği ve gösterişi açıkça ifade etmektedir.

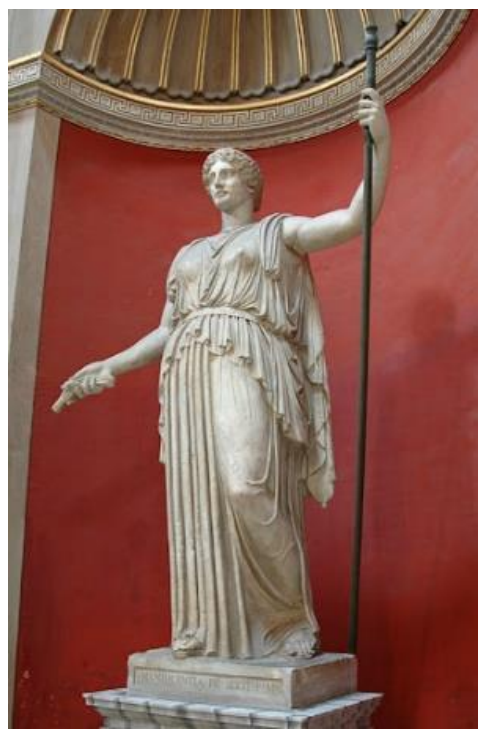

Görsel 4: Demeter, Yunan eserinin Romakopyası, Mermer Heykel, MÖ 420

Heykel sanatında ise kumaşın kullanım alanı resimden daha sınırlı olmuştur. Yontularak biçimlendirilen kumaş ikonografik anlatımın dışında heykelin sanatsal formuna hizmet etmiştir. Örneğin, klasik heykel sanatında Milo Venüsü'nün çıplak bedenindeki kumaş, heykelin anatomik sağlamlığını pekiştirmektedir. Ayrıca Neoklasik döneme kadar estetik mükemmellik ideallerinin bir yansıması olarak kabul edilen Apollo Belvedere heykelinin kolundaki kumaş da heykelin postür ve anatomisine destek vermek için konumlandırılmıştır. Antik dönemdeki birçok sanatçıya ince işçiliği gösterebilmesi için kumaş yapma görevi verilmiştir. Yunan sanatındaki kumaş, bu tür yapısal işlevleri yerine getirmenin yanı sıra, vücudu avantajlı bir şekilde ortaya çıkarmak, figürün hareketini ve hatlarını vurgulamak için de betimlenmiştir. Yunan sanatında bedenle kumaşın arasındaki ilişki karmaşık ve karşılıklıdır. Vatikan Sala Rotonda'da bulunan Demeter heykelinde (Görsel 4) anatomi kumaşın vurgulanması amacıyla deforme edilmiştir. Heykelde omuzlar orantısız bir şekilde genişlemiş ve gögüsler ayrılmış ve kumaş aşırı geniş bir göğsün üzerine yerleştirilmiştir. Kumaşın kıvrımları, üst gövdeyi ağırlaştırmadan veya kayma tehlikesi olmadan zarif bir şekilde kolların üst kısımlarında toplanır ve elbisenin üst kısmı göğüslerin üzerine uzanarak tatmin edici bir tepe ve kanal sistemi oluşturur. Özellikle Klasik Dönem'e ait Yunan kumaş temsilleri beden ile bütünleştiğinde anlam ve önem kazanır. Kumaşın bu hali, erken Mısırlıların veya Arkaik Yunanlıların hayal gücüne hitap etmemiş gibi görünse de sanatta kumaş kullanımı her zaman bir üsluba hizmet etmiştir (Hollender, 1975, s.417-418).

Helenistik dönemde keten, pamuk, yün ve ipek kumaşlar kat kat kıvrımlarıyla sanatçılara ilham kaynağı olmuştur. Sofistikelik, cinsel çekicilik, güç ve sadelik kavramları bu dönemde vücudun etrafına yerleştirilen doğal dokulu dikdörtgen biçimli kumaşlarla ifade edilmiştir. Beden ve kumaş, bağlantılarının mantığı ne olursa olsun Antik Yunan sanatında sanatsal doğruluk ve estetik kriterlerini koruyarak betimlenmiştir. "Kumaş ve bedenin diyalektiği, Yunan sanatının sırrıdır ve kumaşın görünmediği sanat eserlerinde de yokluğu hissedilir” (Hollender, 1975, s.419).

Gotik ve Barok dönemlerinde dökümlü kumaş geçmişe nazaran daha dramatikleştirilerek ve az kullanılmıştır. Bu yaklaşım, Rönesans'ın aksine, kumaşı vücudu ifade eden bir imge olarak 
düşünmemekten kaynaklanır. Yunan sanatında kumaş anatomiye hizmet ederken Barok dönem Bernini heykellerinde enerji ve dinamizmin kaynağıdır.

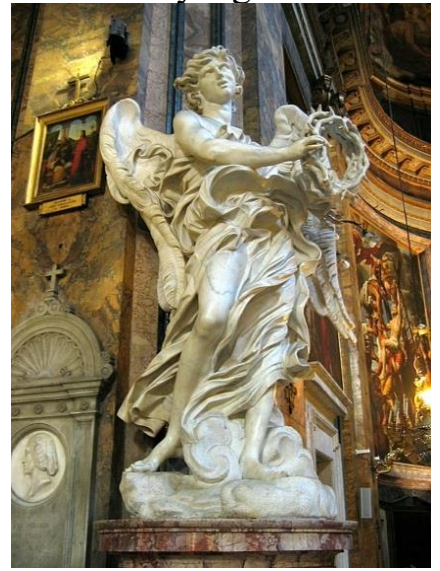

Görsel 5: Giovanni Lorenzo Bernini, Dikenli Taçlı Melek, Mermer Heykel,1668-1671

Bernini, Dikenli Taçlı Melek heykelinde (Görsel 5) eşsiz yeteneği ve ustalığıyla kumaşı rüzgârda dalgalanıyor veya havada uçuyormuş gibi göstererek, heykelin doğasındaki kütlesel ağırlık hissini dönüştürmüştür. Rönesans'ta bedenle bütünleşen kumaş asaleti temsil ederken Barok heykelindeki "asalet", bedenden bağımsız olarak kumaşın kendisinde var olur. Kumaşın figürün hareketini daha estetik bir biçime sokma işlevi ilk defa natüralist heykel sanatıyla kendini göstermiş ve Avrupa'da bundan sonra gelen tüm nesiller bu kullanımı takip etmişlerdir.

Yirminci yüzyılla birlikte değişen dünya dinamikleri ile sanattaki klasik yaklaşımlar sona ererek sanatın düşünsel biçimde algılandığı yeni bir dönem başlamıştır. Alışılmış sanat nesnelerine yeni malzeme, teknoloji ve diğer pek çok üslup eklenerek bu nesnelerin kavramsal bir duyumsama aracılığıyla algılanması sağlanmıştır. Kumaş, sanatta sonu gelmez temsil nesnesi olma özelliğini bu dönemde de devam ettirmiştir. Paul Cézanne ve sonrasında Kübistler, kumaşı, temsil dilinin bir parçası olarak görüp son derece ayrıntılı olarak incelemiştir. Matisse sanat yaşamının büyük bir kısmında kumaş formunu resmin bütününde ele almaya çalışmıştır. "Modern sanatın en temel karakteristiği onun aşırı bir sübjektivizmi beraberinde getirmiş olmasıdır. Gördüğü şeyi resmetmek sanatçıya sonsuz bir çalışma özgürlüğü sağlar ve bu özgürlük içinde klasik formlar parçalanır" (Tunal1, 2011, s.104).

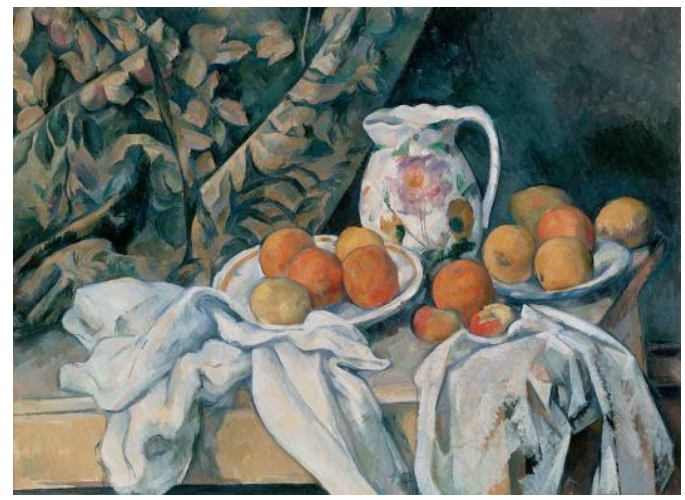

Görsel 6: PaulCezanne, Perdeli Na tümort, Tuvalüzerine yağlıboya, 75x55cm, 1898

Özellikle empresyonist resimlerde formların parçalanmasının yanı sıra sanatın simetri, denge açıklık gibi temel güzellik prensipleri de değişmeye başlamıştır. Cezanne'nın natürmort 
serilerindeki (Görsel 6) kumaş nesnesi sanatçının sübjektif algısının tuval üzerindeki ifadesidir. Perdeli Natürmort eserindeki dökümlü perdeler sadece estetik bir nesne olarak izleyicinin duyularına hitap eder ve hoşlanma duygusu meydana getirir. "Güzel, hoştur ya da başka bir deyimle söylersek güzel hoşlanmanın objesidir" (Tunalı, 2011, s.104). Dolayısıyla empresyonizmde kumaş yalnızca estetik bir obje olarak hoşlanma duygusunu tetikleyen bir fenomendir.

Çağdaş sanatın düşünce biçimi ve çoğulcu malzeme yaklaşımı kumaşın kullanım biçimlerinin değişmesine ve yeni kavramları temsil etme yetisinin gelişmesine yol açmıştır. Alberto Burri kumaşı rastlantısal yöntemlerle tuvale yerleştirirken onu bir anlatı nesnesine dönüştürmüştür. 1945 yılında savaşta esir düştüğü esnada ulaşabildiğgi tek nesne olan çuval, çalışmalarında, savaş esnasında yaşadığı acı ve ızdırabın temsilidir (Görsel 7). Atık malzeme olarak bulduğu çuvallara dikiş, boyama, katlama, yapıştırma, kesme, yırtma gibi teknikleri uygulamıştır.
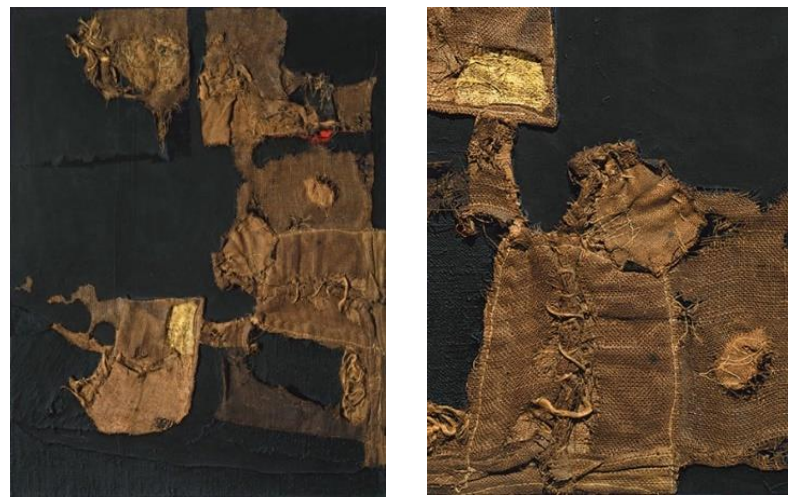

Görsel 7: Alberto Burri, Çuvalve Altın, Siyah Kumaşüzerine Çuval Bezi, İplik, Varak,86x x 101 cm, 1953

Tuvalin yapıbozumcu sanatçısı olarak adlandırılan Amerikalı Robert Rauschenberg atık, kumaş çeşitlerini yeni bir ifade aracı olarak kullanmıştır. 'Rauschenberg' in 'Yatak' adlı eserinde, (Görsel 8) yama ve yorgan gibi geleneksel değerler, renklerin ve boyaların özgür dışavurumunu yansıtan geleneksel olmayan yeni bir ifade yöntemiyle birleştirilerek sunulmuştur" (Arabalı Koşar, 2017, s. 2041). Sanatçının tuval bezi yerine geçen bu çalışmasındaki yorgan, sıradan bir ev nesnesinden kültürün sınırlarının sorgulandığı bir temsil nesnesine dönüşmüştür. Sanatçı bu çalışmayla yaşadığı dönemdeki Amerikan toplumunun yaşantısına eleştirel ve ironik bir tavır göstermiştir.

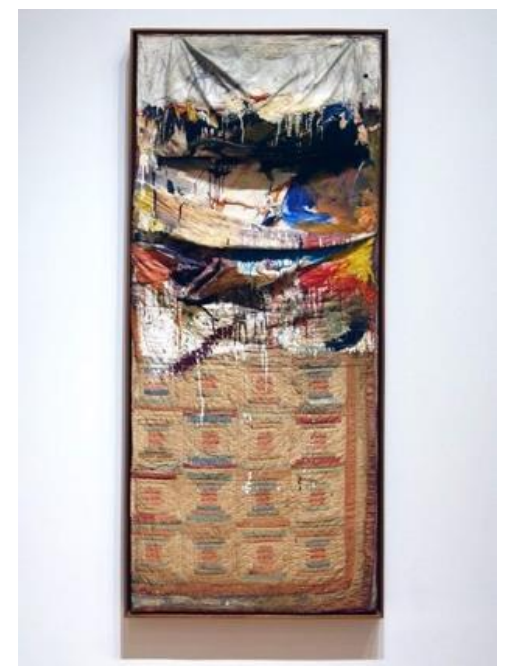


Görsel 8: Robert Rauschenberg, Ya tak, Ahşap üzerine Yorgan, Çarşaf, Yağlıboya, 191.1x20.3 cm, 1955

Çağdaş sanat doğal ve yapay malzemelerin, farklı kavramların ifade aracı olarak kullanıldığı bir dönemdir. $\mathrm{Bu}$ süreçte Arte Povera'nın en önemli temsilcilerinden Michelangelo Pistoletto, Paçavraların Venüs'ü adlı çalışmasında (Görsel 9) kumaşlarla tüketim kültürüne ironik bir yaklaşım sunar. Antik dönemden bir heykel olan Venüs heykelinin önüne yığdığı kullanılmış kumaş yığınları ile gerçekleştirdiği enstelasyonda kumaşa yüklediği misyon "paçavra" olarak nitelendirilmiştir. Venüs'ün yüzünü duvara dönmesi geçmişteki imgesiyle var olamadığını simgeler. Venüs'ün paçavra kumaşlar arasındaki görüntüsü günümüz tüketim nesneleri arasındaki yok oluşunu temsil eder. Tarihsel bir ikon ile güncel bir tüketim nesnesinin bu kaotik düzenlemesi; kumaş yığınları, renkleri ve rastlantısal duruşları ile desteklemiştir.

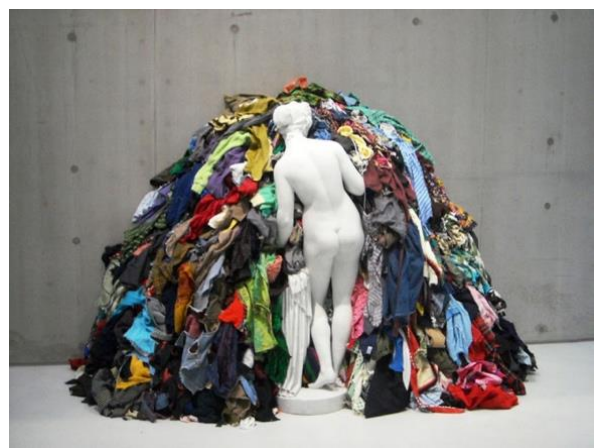

Görsel 9: Michelangelo Pistoletto, Paçavraların Venüs’ü, Beton, Emaye, Kumaş,1967.

İkinci Dünya Savaşı sonrasında çağdaş sanatın en tartışmalı sanatçılardan Joseph Beuys'un heykel, enstalasyon, çizim ve performans alanlarındaki çalışmalarında şamanizmden etkiler görmek mümkündür. Beuys, Rudolf Steiner'in antropozofi öğretisinden etkiler taşıyan ezoterik ve mistik kavramlar kullanmıştır. "Kır Kurdu. Amerika'yı Seviyorum Amerika'da Beni Seviyor” isimli performansının genel bağlamı da şamanist dünya görüşüyle ilişkilidir (Görsel 10). Beuys'un çalışmalarında seçtiği malzemeler eserlerin anlamlarını şekillendiren unsurlardır.

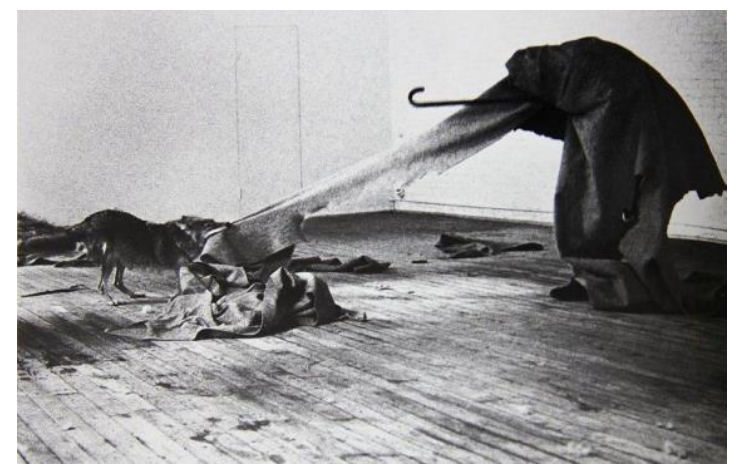

Görsel 10: Joeseph Beuys, Kır Kurdu. Amerika’y1 Seviyorum Am erika'da Beni Seviyor,1974

Beuys'un bir kır kurdu ile üç gün geçirdiği, Rene Blok galesindeki performansında, keçe önemli bir ifade aracıyd. Merdaner bu performans sürecini şu şekilde ifade eder;

“Beuys New York'a uçakla gelir gözleri uçaktan inmeden önce bağlanır. Havaalanında keçeye sarllır ve ambulansla sedyeye yatırllarak galeriye getirilir. Beuys gösterinin devam ettiği üç gün boyunca her seanstan önce yerdeki keçe parçalarından birine sarllır ve yere 
yatmış bir şekilde bir süre durur. Bu süre içerisinde kurt, Beuys'un hareketlerini izler keçeyi koklar ve isırarak koparmaya çalışır. Beuys da yavaş yavaş üzerindeki keçeden kurtulur. Performans bitiminde Beuys gözleri kapatılarak keçeye sarıl bir şekilde ambulansla havaalanına götürülür ve Almanya'ya geri döner" (2016, s. 91-92).

Beuys bu performasında keçeye sarılarak kendi doğal alanını belirlemiştir. Kır kurdu keçeye her temas ettiğinde Beuys'un alanına girerek ikisi arasındaki iletişimi gerçekleştirir. Keçe Beuys'un diğer çalışmalarında da benzer anlamlarla var olur. İkinci Dünya Savaşı sırasında Alman Hava Kuvvetleri'nin bir üyesi olarak uçağı Kırım Cephesi'nde düştüğünde Tatar kabileleri hayvansal yağ ve keçe kullanarak hayatını kurtarmışlardır. Dolayısıyla yaşamsal bir bağ kurduğu keçe, Beuys'un çalışmalarında koruyucu ve hayat veren bir kumaşı temsil etmektedir.

1970'ler, feminizmin hem en çok tartışıldığı hem de en provakatif olduğu bir dönemdir. Özellikle kadınla ilişkilendirilen nesneler, semboller ve kavramlar sanatta, politikada ve pek çok alanda eleştiri konusu olmuştur. Bu nesnelerden biri olan kumaş, hem üretimi hem de süslemeci yapısı itibariyle yüzyıllarca kadına atfedilmiş bir malzeme olarak algılanmıştır. Kadınlığın temsili olarak sunulan kumaş, Judy Chicago'nun “Akşam Yemeği Partisi”” çalışmasında bu durumu eleştirmek adına kullanılmıştır. Sanat tarihindeki yapılandırılmış toplumsal cinsiyet rolleri, kumaşın feminen bir nesne olarak kabul edilmesine neden olmuştur. Dolayısı ile feminist sanatçılar formların ve nesnelerin hiyerarşilerini sorgularken kumaşın alışagelmiş temsilini de yeniden inşa etmeye çalışmışlardır. Feminist sanatçılar, görsel kültürdeki kadınlığın gereği olarak kodlanmış annelik ve eş olma gibi toplumsal varsayımlara meydan okurken kumaşın anlatım olanaklarını çeşitlendirmişlerdir. Dorothy Cross'un 1993 tarihli "Bakire Örtüsü” (Görsel 11) isimli çalışması güçlü ama hayaleti andıran bir Meryem Ana imgesini çağrıştırır. İrlanda'lı sanatçı Botticelli (1485) veya Raphael (1505) gibi sanatçılar tarafından resmedilerek ikonlaştırılmış kutsal bakire (Meryem Ana) figürünü olağandışı bir şekilde çift tonlu sığır derisi ve kumaşlarla kaplayarak görkemli ancak hayalete benzer bir Meryem'e dönüştürmüştür. Alışılmışın aksine bu enstalasyonda kutsal bakire, bir kaide üzerinde değil, Cross'un büyükannesinin 1914 tarihli narin, saten parlaklığındaki ipeksi gelinliğinin içinde, çürük bir elbise askısında durmaktadır. Cross, üst üste bindirdiği uzun kumaş yığınlarıyla iki metre yüksekliğinde ve bir metre genişliğinde güzel ama ürkütücü bir figür oluşturur. Parlak beyaz gelinlik, cinsel farkındalığı olmayan genç bir gelinin saf halinin göstergesi olarak bekâreti çağrıştırmaktadır. Sı ̆̆ır derisi ise, kadını doğaya bağlayan hayvansal bir bağlantıdır. Sanatçı, güçlü bir figür aracılığıyla ürkütücü bir kadınsılık önerir. Bastırılmış dürtülerin ve tehlikeli arzuların birbirine karıştı̆̆ semiyotik rezervden ortaya çıkan bu çalışmada kutsal bakire bizi tekrar tekrar ziyaret ediyor gibi görünmektedir.

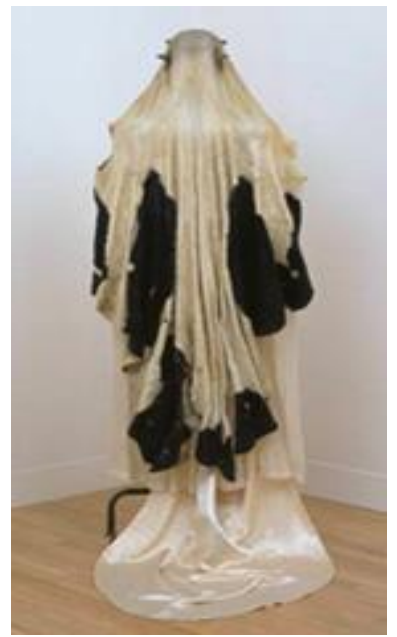


Görsel 11: Dorothy Cross, Bakire Örtüsü, Kasnak, Saten kumaş, Deri, 210 x 100 cm, 1993

"Bakire Örtüsü" çalışmasında yüzü olmayan bakirenin başının üzerinde şeytani bir taç gibi düzenlenmiş meme uçları, abartılı dökümlü kumaşlar kadın cinselliğini çağrıştıran göstergeler dir . "Tüm bu göstergeler ölümü, doğurgan bir anneyi, üreme ve yeni yaşam anlamlarını temsil etmektedir" (Turton, 2012, s.7). Kadınlık ve annelik içgüdülerini kumaşlarla ifade eden diğger bir sanatçı da Sarah Meyers Brent'dir. "Annem Beni Sever III" (Görsel 12), adlı çalışmasında kumaşların tuvalden taşması insani duyguların yoğunlaşma durumunu ifade etmektedir. Brent'in annelik vizyonundaki duruşu tuval yüzeyindeki karmaşa ve kaygı olarak aktarılmıştır. Biçimsel ve tematik olarak annenin ve bebeğin yaşadığı duygu durumları ve hormonal aktarımlar, kumaşların rengi, dokusu, hacimleri ile belirgin hale gelmiştir. Püskürtme köpüğüyle açılmış tuval, çamaşır düğümleri aracılığıyla kaotik ortamına ve doğumun şiddetine gönderme yapmaktadır. Bununla birlikte kumaşları süsleyen sitilize bombus arıları, tırtıllar ve filler kaotik ortama tezat oluşturulacak bir hava katmaktadır. Tuvalin altına düşen kumaş parçaları da kompozisyonun devamlılığını sağlarken yorgunluk ve yıpranmışlık ifadesini desteklemektedir.

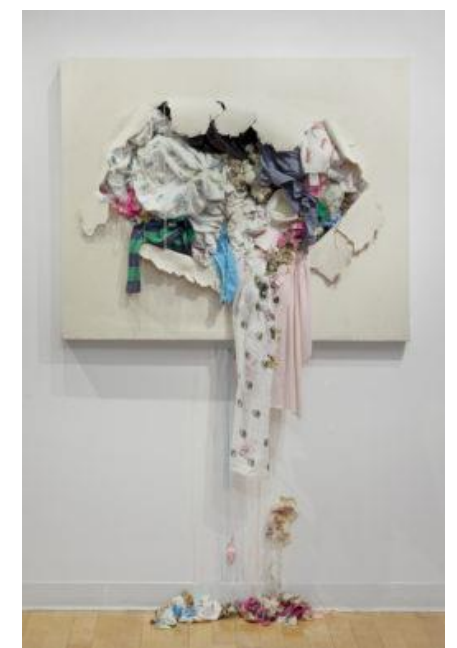

Görsel 12: Sarah Meyers Brent, Annem Beni Sever III, Tuvalüzerine Kumaş, Akrilik, Köpük, 77,5 x 50 cm, 2017

Kumaş; rengi, dokusu ve sahip olduğu kültürel kodları ile Gülsün Karamustafa'nın çalışmalarında belirgin bir temsil aracıdır. Karamustafa'nın 1992'de sergilediği enstalasyonda kullandığı geleneksel Türk yorganları; etnik kimlik, göç, cinsiyet rolleri gibi konuları odağına almıştır. Genellikle çalışmalarında kitsch kavramına yer veren Karamustafa, burada kumaşın renk ve dokularında ucuz ve yoz kavramlarını harmanlayarak kitsch eleştirisinde bulunmuştur.
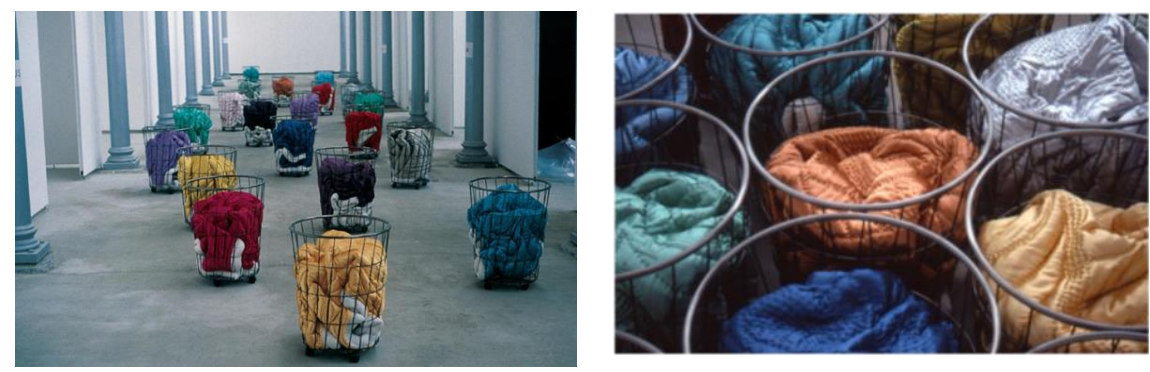

Görsel 13: Gülsün Karamustafa, Mistik Nakliye, Enstalasyon, 1992 
Sanatçının 3. İstanbul Bienali'nde sergilenen "Mistik Nakliye" (Görsel 13) adlı çalışması köyden kente göçle birlikte kültür değişimlerine dikkat çeken bir eserdir. Enstalasyonda rengârenk geleneksel Türk yorganları demir küfelerin içlerine yerleştirilmiştir. Diğer eserlerinde oldu ğu gibi bağlamından koparılmış, yeni bir yere yerleştirilmiş melez nesneler karşımıza çıkmaktadır. Bu nesneler aracılığı ile köyden kente göç ile değişen hayatlar, hafıza, bellek, anı, kültür gibi kavramların yer değiştirmesi ve tüm bunlara bağlı olarak yersizleşme-yurtsuzlaşma olgusu aktarılmaktadır. Dramatik bir hikâyenin anısı ve hatırlatığıdır bu. Gündelik yaşamda altına sığınılan yorganların, hayatı da temsil ettiği düşünülebilir (Çalışkan, 2019, s. 104).

Çağdaş sanatta kumaş multidisipliner çalışan sanatçılar için vazgeçilmez bir anlatı nesnesi olmuştur. Nurveen Barwari de kumaşı bir hafıza nesnesi olarak düşünüp yorumlayan sanatçılardandır. Kültürlere ve topluma mal olmuş kumaşları ironik bir deneyim ile kompoze etmektedir. Yer yer tüketim toplumuna karşı popüler eleştiriler yapan, moda ve çağdaş sanat gibi konuları ele alan sanatçı, kumaşı tuvalde dengeli ve zengin derinlikler ile sunmaktadır. "Sanatçı vatansız bir topluluğun parçalanmış diasporik yaşamı ve üyelik durumlarını etkenler üzerinden şekillendirip; göç, mültecilik, kimlik, yeniden yerleştirme mücadeleleri gibi kavramları alt başlık olarak sıralıyor" (Tan, 2020). Kumaş dokusu sanat alımlaması noktasında Barwari için kendiliğinden çoğulcu bir görüngü olup, her yeni bir okumayla da kendisini sil baştan yaratmay1 sağlamaktadır. Özellikle "Nerde Kadınlar Orda Pantolon" isimli çalışmasında kimlik ve cinsiyet sorununa değinmektedir. Kumaşların renkli, dokulu ve hacimli kullanımı sanatçının doğup büyüdüğü bölgenin kullandığı kumaşların dilini yansıtmaktadır.

Kumaşın bir anlatı nesnesi olarak mitoloji, din, kadın, kültür, kimlik, cinsiyet gibi geniş temsil etme olanakları çağdaş sanatın vazgeçilmez malzemesi haline gelmesini sağlamıştır. Ahmet Güneştekin'in "Kırkyama" serisi kadın, kültür ve kimlik konularını içeren çalışmalardan oluşmaktadır. Sanatçı "Kırkyama" serisinde, kumaşların renk, desen, dikim biçimlerini kültürel kodlara göre sentezlemektedir. Güneştekin serisiyle ilgili;

"Yama bir fragmandır. Kaybolan bir şeyin işareti ve yaratıcı tasarıma meydan okuma olarak duran bir bütünlük zaafidır. Kalan olarak, yama yırtılma ve bozulmayl sembolize edebilir; çoktan yitip gitmiş olanın solmuş görkemiyle tanımlanabilir. Ancak, bir parça olarak, henüz keşfedilmemiş olanın patlayıcı potansiyeline de sahiptir. Parçaların bir araya getirilmesi, formların karmaşlk bir matriste düzenlenmesi, ilerlemeye bir alternatif olarak derinlik ve yoğunluk gösterir. Geçici fakat uyarıcı parçaları bir anlatı olarak okunabilecek bir formda toplama ve birleştirme süreci ise kadına özgüdür" (Yurtalan, 2019).

"Kırkyama" serisinde sanatçı, kumaşlar aracılığıyla geçmiş ve gelecek arasında bir sentez gerçekleştirmektedir. Özellikle geçmiş olgusunu anne ve büyükannelerinin kırkyama yaratıcılığına atıf yaparak gerçekleştirmektedir. Eski kıyafetlerle yapılan kırkyamaların yıkım sonrası yaratıma işaret ettiğini savunan Güneştekin, hayata karışma ve onun bir parçası olmayı kırkyamalar aracılığıyla sağlamaktadır.

Gerçeküstücü kavramsal fotoğrafçı Nicolas Bruno'nun "Somnia Tarot” adlı son sergisinde, karabasan sonrası oluşan uyku felci deneyimini anlatmaktadır. Bu çalışmalarıyla sanatçı ömrü boyunca muzdarip olduğu uyku felci mücadelesiyle yüzleşir. Yaşadığı karabasan sonrası uyandı ğ 1 anda rüyalarını çizerek sanatsal sürecini başlatan Bruno, uygun dekor ve kostümleri tasarlamaya başlamaktadır. Sanatçı bu süreçte katartik yolculuğunun her adımını temsil ederek ve kaydetmektedir. 

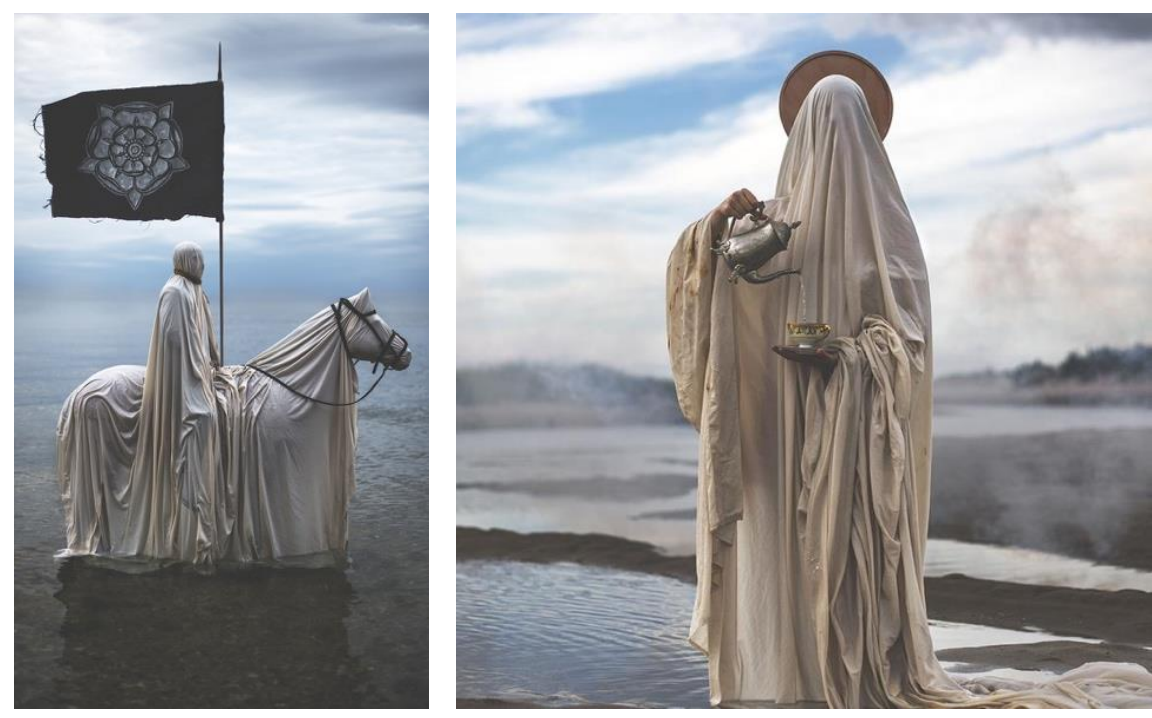

Görsel 14: Nicolas Bruno, Ölüm ve Denge, DijitalFotoğraf, 2020

Sanatçının tarot kart destesinden esinlenen "Somnia Tarot" serisindeki "Ölüm ve Denge" (Görsel 14) isimli fotoğraf, uyku felci anını güzel rüya manzaralarıyla betimlediği bir çalışmadır. Bruno, fotoğraflarındaki karakterlerin, ruh hallerini, sembolik nesnelerini ve arka planlarını, Majör Arkana ve Minör Arkana tarot kartlarından etkilenerek uyarlamaktadır. Görsel bir rüya dili yarattı̆̆ 78 adet dijital fotoğraf serisinde figürlerin üzerindeki kumaşları, bilinci örten, kapatan temsiller olarak sunmaktadır (Sharples, 2021). Bruno'nun çalışmalarında kumaşın örtücü özelliği figürü tektipleştirirken vücudun yaşamdan ölüme geçişteki belirleyici unsuru haline gelir. Madde ile ruh arasındaki çatışmada bir katalizör görevi gören kumaş izleyicide gizem duygusunu da harekete geçirir. Micheal Kimmelman'in "sarılı her şeyde bir gizem havası bulunur, içindekinin çok kıymetli olduğu kanısını uyandırır. Bir nesneyi peçelemek ona erotik bir anlam da katabilir. Örtüldüğünde kumaşın altında ki sert şekil zarifleşir ve yumuşar" (Kimmelman, 1995, s.56) ifadesi Bruno'nun eserlerini açıklar niteliktedir. Sanatçı görkemli ve dökümlü kumaşları hem figürlerin kapalı bilinçlerini vurgulamak hem de onları klasik Yunan heykelleri gibi göstermek için kullanmıştır. Ayrıca sanatçının kumaşı yumuşak dokusundan uzaklaştırması figürü mermer ya da taş etkisi veren bir metaforik bir yaklaşımla ele aldığını göstermektedir.

Arazi sanatında da; kumaşın özgün üretim biçimleri ve sanatsal ifadesi doğaya ve çevreye taşınmıştır. Kumaşın dokunsal zenginliği, esnekliği, örtücülüğü, buruşturulabilirliği, sökülüp dikilebilirliği, yani dışarıdan yapılan fiziksel ve kimyasal müdahalelere karşı verdiği tepkisel özellikleri arazi sanatı sanatçılarının ilgisini çekmiştir. Yapısal özelliğinin dışında çoklu anlamsal çağrışımları içeren kumaş nesnesi Christo ve Jean Claude çiftinin üç boyutlu uygulamalarında görülür. Christo ve Jean Claude çifti kumaşın fonksiyonelliğinin yanında, görselliğini de ön planda tutarak gerçekleştirdikleri uygulamalarında mimari yapının üzerini örterek cephe yüzeylerine hareket ve boyut kazandırmayı amaçlamışlardır. Böylece mimari yapılar detaylarından arındırılmış, sanatsal ve kavramsal bir ifade aracına dönüşmüştür. Christo ve Jean Claude'un binaları kumaşla kapladıkları çalışmalarında binaların bulundukları çevreyle uyumlu kumaş renkleri seçmeleri izleyici üzerinde çarpıcı bir etki bırakmaktadır. Her çalışma için farklı tipte kumaş kullanmış olsalar dahi kumaşların ortak noktası hiçbir yapay katkı maddesi içermeyen doğal ve yeniden işlenebilen kumaşlar olmalarıdır. 

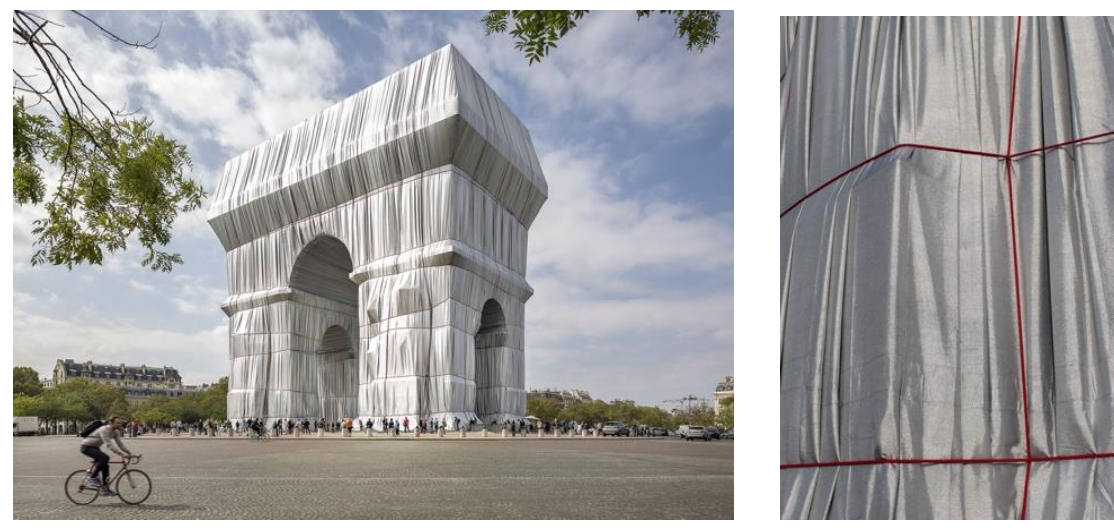

Görsel 15: Christo ve Jeanne Cla ude, Ka planmış L'Arc de Triomphe, Kumaş, İp, Arc de Triomphe, 2021

Paris'te bulunan 1800 yılında inşa edilen Arc de Triomphe anıtının kumaşlarla sarılması ile gerçekleştirilmiş "Kaplanmış L'Arc de Triomphe" isimli çalışma (Görsel 15), Christo ve Jeanne Claude çiftinin 1961-2019 yılları arasında çeşitli çizim, kolajlarla devam eden ve onların yıllardır hayalini kurdukları bir eserdir. Gümüş mavisi 25.000 metrekarelik geri dönüşebilir polipropilen kumaş ve 3.000 metre kırmızı iple sarılarak uygulanmış bir projedir. Çiftin hayali olan proje onların vefatından sonra yeğenleri Vladimir Yavachev tarafından gerçekleşmiştir. 30 yıl boyunca Christo ile birlikte çalışan projenin operasyon direktörü Yavachev, kumaşın parıldayan renginin ve canlı iplerin, Christo'nun Fransız bayrağının mavi, beyaz ve kırmızısına "şiirsel yorumu" olarak açıklamıştır (Palumbo, 2021). Christo ve Jean Claude'un çevreci bir tavırla sergiledikleri "Kaplanmış L'Arc de Triomphe" isimli yapıtında binanın dış yüzeyi, düşey katlamalardan oluşan bol dökümlü kumaşla çok etkileyici bir görünüme büründürülmüştür. Kumaş proporsiyonlarının etkisi strüktüre görkemli bir görünüm sağlarken kumaşın gümüş mavi rengi yapıya parlak metal bir görünüm kazandırmıştır. David Bourdon; Christo Jeanne Claude çiftinin sanatını "gizlilik içinde ifşaat" (Doğan, 1995, s. 108) olarak tanımlamaktadır. Tarihsel ve siyasi geçmişiyle önem kazanan Arc de Triomphe anıtının kumaşla kaplanmış hali gizemli bir uyum içerirken mesaj verme kaygısından çok yeni bir gerçeklik ortaya koymayı amaçlamıştır. Christo eserlerindeki kumaş kullanımı için şunları söylemiştir;

"İnsanların kendilerine ve çevrelerine daha bilinçli yaklaşmalarına yardımcı olmaya çalışıyoruz. Bir projeye başladığımda sonucunun nasıl olacağını tam olarak bilmiyorum. Projelerimde çoğunlukla farkl tiplerde de olsa daima kumaş kullanmayl tercih ediyorum. Çünkü kumaş, dinamik ve dokununca karşıllk veren bir materyal olarak, en ufak esintide bile hareketlenebilmektedir" (Keser ve Oskay, 2015, s.84).

Mimaride kumaşın kavramsal ve estetik yönüyle kullanılması yapının, çevreyle uyumuna işaret etmektedir. Kumaşın mimari bir yapıyla yorumlanması öncü ve sıra dışı özellikler içermektedir. Christo-Jeanne Claude çiftinin kumaşlarla gerçekleştirdiği devasa projeler popüler bölge ve yapıları ikonlaştırmaktadır.

\section{Sonuç}

Yaşamın vazgeçilmez nesnesi olan kumaş, tarih boyunca hem bir kültür nesnesi hem de sanat nesnesi olarak metaforik bir ifade aracıdır. Bu özellikleriyle sanatta ikonografik bir içeriğe sahiptir. Sanat tarihi boyunca yapısı gereği her forma girebilen kumaş nesnesi, sanat yapıtlarında farklı konu ve kavramları temsil edebilme özelliğine sahip olmuştur. Bu sebeptendir ki insanlık ve sanat var olduğu sürece kumaşa duyulan ilginin süreceği görülmektedir. 
Batı sanatında, Antik dönem Yunan sanatında ve Rönesans’tan itibaren önemli bir yer edinmiş kumaş nesnesi, formu destekleme, bedeni güzelleștirme, asalet ve yücelik kavramlarını temsil etme özelliğiyle öne çıkmıştır. Sanat tarihinin neredeyse tüm dönem ve üsluplarında kumaşın farklı yöntemlerle ifade gücüne tanıklık etmek mümkündür. Böylesine uzun bir zaman dilimine ve coğrafi alana yayılmış olan kumaş, sanatta resim, heykel, enstalasyon çalışmalarında biçimi zenginleştirip eserin anlatımına katkı sağlamıştır.

Rönesans döneminde kumaş, bedenden ziyade ruhsal olanı temsil ederek sanatçıların hayal gücünü tetikleyen bir unsur olmuştur. Klasik dönem resim sanatında sanatçlar, ifadeyi güçlendirmek için kompozisyonun büyük bir kısmını özellikle kumaşlara ayırmışlardır. Klasik sanatta kumaş bir anlatı nesnesi olarak çoğunlukla üstüne örtüleni ortaya çıkarmak için kullanılmıştır. Eserlerde insan bedenini gizlerken dahi onu öne çıkaran ve güzelleştiren uhrevi anlamlar taşımaktadır. Ayrıca bu dönemde kumaşın akışkan formu, biçimsel esnekliği kompozisyonlarda ritmin hareket ve enerjinin ortaya çıkmasına yol açmıştır. Modern sanat eserlerinde ise kumaşın sanatta kullanımını etkileyen yeni bir sanat anlayışı gelişmiş ve geleneksel üsluptan kopuş başlamıştır. Kumaş imgesi, klasik resim sanatında sanatçının figürü belirginleştirmesi için bir aracıyken modern sanatta baskın bir özne olarak biçimsel ve ifadesel nitelikleriyle ortaya çıkmıştır.

Kumaşın formun örttüğ̈ kütlenin biçimine bağlı olması durumu çağdaş sanatta örttüğü nesnenin simüle edilmiş varlığ 1 ile birleşmektedir. Klasik resim veya heykelde kumaş, bedenlerin biçimlerini gizleyen ve gizeminin görüntüsünü yansıtan ikonografik bir motifken çağdaş sanatta siyasi, sosyal, cinsel, dini veya kültürel gerilimleri yansıtan bir temsil nesnesi olarak kullanılmaktadır. Kumaşın sanattaki temsilleri postmodern durumun kendini belirleyen ana hatları ile bağlantılı olarak değişkenlik göstermiştir. Yeni sanat üretim yöntemlerinde bellek, kimlik, cinsiyet, kültür aktarımcısı gibi pek çok misyon yüklenen kumaş; yırtık, kesik, boyalı, parçalı, işlemeli, katlanmış ya da düzensiz formları ile soyut kavramları ifade eden çok yönlü bir metafora dönüşmüştür. Bu dönüşümün post modernizmin yıkma, parçalama ve yeniden üretme edimiyle örtüştüğü söylenebilir.

Kumaşın göstergebilimsel açıdan hem gösterileni hem de gösterilemeyeni temsil etmesi sanatta bir katalizör görevi üstlenmesini sağlamıştır. Dolayısıyla çok yönlü anlatımı farklı teknik ve konulara uygulanabilir oluşu ile kumaş, çağdaş sanatta disiplinlerarası bir temsil nesnesine dönüşmüştür. Kumaşın gündelik hayat içerisindeki işlevsel, kültürel ve sembolik anlamları düşünüldüğünde sanat var oldukça onun nesnesi olamaya devam edeceği öngörülmektedir.

\section{Kaynakça}

Arabal1-Koşar, S.T. (2017). “Çağdaş Sanat Disiplinleri Arası Etkileşimlerde Lif Sanatı”. İdil. 6(35). 2035-2059.

Brady, B. ve Barton G. (2013). Exploring the Image of Drapery in Works of Art, http://jur.byu.edu/?p=7601. (Erişim Tarihi:25.09.2021)

Cevizci A. (2013). “Temsil”, Felsefe Sözlüğü. İstanbul: Paradigma Yayınları

Çalışkan S. (2019). "Gülsün Karamustafa'nın Eserlerinde Köyden Kente Göç ve Kimlik Olgusu”. Klrklareli Üniversitesi Sosyal Bilimler Dergisi (E-Issn: 2602-4314) 3(2) 97-106.

Doğan, H. (1995), "Christo ve Paketlenen Parlamento Binası". Yapı Dergisi (163). 104-111.

Dixon, A. G. (2016). Drapery and the Secret History of Painting, https://www.christies.com/features/Drapery-and-the-secret-history-of-painting-7152-1.aspx Erişim tarihi:22.09.2021)

Francalanci, E. (2012). Nesnelerin Estetiği. (D. Kundakçı, Çev.). Ankara: Dost Kitabevi. Gaiger, J. (2003). Frameworks for Modern Art. Singapore: Open University Press. 
Goodman, N. (1976). Languages of Art an Approach to a Theory of Symbols, Hackett Publishing Company, INC, Indianapolis, USA.

Hogarth, W. (1753). The Analysis of Beauty. C. Davis, (Ed.). London: Printed by John Reeves Hollander, A. (1975). The Fabric of Vision: The Role Of Drapery In Art Source. The Georgia Review 29-2. 414-465.

Keser,C. S. ve Oskay, N. (2015). Çevresel Sanat Bağlamında Christo- Jeanne Claude Çiftinin Disiplinlerarası Üç Boyutlu Tasarım Uygulamalarında Tekstil Kullanımı. Turkish Studies International Periodical for the Languages, Literature and History of Turkish or Turkic (10/14) 71-88. (https://www.researchgate.net/publication/309390279_(Erişim Tarihi: 21.10.2021)

Kimmelman, M. (1995) “Büyük ve Eğlenceliydi, daha ne olsun?” (M. Mjaanes, Çev.) Türkiye’de Sanat Dergisi, (20). 56-57

Merdaner, E. (2016). Joseph Beuys-Sanatı ve Felsefesine Bir Bakış, İstanbul: Tekhne Yayınlar1

Özkendirci, B. (2019). "Çağdaş Sanatta Bireyin Giysiyle Temsil Edilmesi” Sdü Art-E Güzel Sanatlar Fakültesi Sanat Dergisi. 12(24) 677-693.

Palumbo, J. (2021). The Arc de Triomphe is wrapped in fabric, a vision six decades in the making, https://edition.cnn.com/style/article/christo-arc-de-triomphe-wrappedcompleted/index.html (Erişim Tarihi: 13.10.2021)

Platon, (2014). Devlet. (S. Eyüpoğlu ve A. Cimsöz, Çev.) H. Ali Yücel Klasikleri Dizisi. İstanbul: Türkiye İş Bankası Kültür Yayınları

Ramond, S. (2020). Drape Exhibition Catalog, Directeur Général Du Pôle des Musées D’art de Lyon MBA MAC, 203

Sharples, V. (2021). Somnia Tarot Nicholas Bruno, https://www.somniatarot.com/ (Erişim Tarihi: 15.10.2021)

Tan, F. (2020). Çağdaş Sanatın Otantik Formu: Nuveen Barwari, https://www.gazeteduvar.com.tr/kultur-sanat/2020/07/12/cagdas-sanatin-otantik-formunuveen-barwari (Erişim Tarihi:14.10.2021)

Turton, T. (2012). The 'Maternal' Feminist: Exploring The Primal in Women's Art Studies in the Maternal, 4(1).

Yurtalan, A. (2019). Ahmet Güneştekin Berlin'de, https://sonmansethaber.wordpress.com/2019/03/15/ahmet-gunestekinin-berlinde/ (Erişim Tarihi: 15.10 .2021$)$

\section{Görsel Kaynakça}

Görsel 1: https://www.christies.com/features/Drapery-and-the-secret-history-of-painting-71521.aspx (Erişim Tarihi: 11.10.2021)

Görsel 2: https://www.christies.com/features/Drapery-and-the-secret-history-of-painting-71521.aspx (Erişim Tarihi: 11.10.2021)

Görsel 3: https://www.tarihlisanat.com/sandro-botticelli/ (Erişim Tarihi: 1.09.2021)

Görsel 4: http://ancientrome.ru/art/artworken/img.htm?id=1217 (Erişim Tarihi: 19.09.2021)

Görsel 5: http://guide.supereva.it/roma/interventi/2010/06/basilica-di-santandrea-delle-fratte (Erişim Tarihi: 14.10.2021)

Görsel 6: https://tr.painting-planet.com/perdelik-ve-surahi-ile-naturmort-paul-cezanne/ (Erişim tarihi: 01.12.2021)

Görsel 7: https://www.wsj.com/articles/alberto-burri-the-trauma-of-painting-review-1449698460 (Erişim Tarihi: 01.10.2021)

Görsel 8: http://www.banucarmikli.com/sanatin-devrimcisi-robert-rauschenberg/ (Erişim Tarihi: 28.09.2021) 
Görsel 9: https://sanatkaravani.com/pistoletto-ve-yoksul-sanat/ (Erişim tarihi: 20.09.2021)

Görsel 10: https://onedio.com/haber/joseph-beuys-tarafindan-gerceklestirilen-ilginc-bir-sanatolayi-vahsi-bir-kurt-ile-ayni-kafeste-1-hafta-248994 (Erişim Tarihi: 30.11.2021)

Görsel 11: https://www.irishexaminer.com/lifestyle/arid-31001004.html (Erişim Tarihi:

13.10.2021)

Görsel 12: https://www.societyofgreenarts.com/sarah-meyers-brent (Erişim Tarihi: 15.10.2021)

Görsel 13: https://archives.saltresearch.org/handle/123456789/9881 (Erişim Tarihi: 28.09.2021)

Görsel 14: https://www.nicolasbrunophotography.com/ (Erişim Tarihi: 18.10.2021)

Görsel15: https://edition.cnn.com/style/article/christo-arc-de-triomphe-wrapped-

completed/index.html (Erişim Tarihi: 25.09.2021) 